Article

\title{
The Prevalence of Helicobacter pylori in Estonian Bariatric Surgery Patients
}

\author{
Natalja Šebunova ${ }^{1}$, Jelena Štšepetova ${ }^{1,2, *}$, Toomas Sillakivi ${ }^{3}$ and Reet Mändar ${ }^{1,2}$ \\ 1 Institute of Biomedicine and Translational Medicine, University of Tartu, Ravila Street 19, \\ 50411 Tartu, Estonia; natalja.sebunova@ut.ee (N.Š.); reet.mandar@ut.ee (R.M.) \\ 2 Competence Centre on Health Technologies, Tiigi Street 61B, 50410 Tartu, Estonia \\ 3 Abdominal Surgery Department of Tartu University Hospital, Puusepa Street 8, 51014 Tartu, Estonia; \\ toomas.sillakivi@kliinikum.ee \\ * Correspondence: jelena.stsepetova@ut.ee; Tel.: +372-737-4174
}

Received: 12 December 2017; Accepted: 18 January 2018; Published: 24 January 2018

\begin{abstract}
Helicobacter pylori $(\mathrm{Hp})$ is one of the most important human pathogens that can cause duodenal and gastric ulcers, gastritis and stomach cancer. $H p$ infection is considered to be a cause of limiting access to bariatric surgery. The aim of this study was to determine the prevalence of $\mathrm{Hp}$ in patients with obesity going into bariatric surgery and to reveal the relationship between $\mathrm{Hp}$ and clinical data. The study group was formed of 68 preoperative bariatric surgery patients (body mass index (BMI) $44.7 \pm 4.8$ ). Gastric biopsies (antrum and corpus) were used for histological and molecular (caq $A$ and $g l m M$ genes) examinations. The PCR method revealed $\mathrm{Hp}$ infection in $64.7 \%$ of obese patients that is higher in comparison with histological analysis (55.9\%). The prevalence of $\operatorname{cag} A$ and $g \operatorname{lm} M$ genes in antrum mucosa was $45.6 \%$ and $47.0 \%$ while in the corpus it was $41.2 \%$ and $38.3 \%$, respectively. The coincidence of both $\operatorname{cag} A$ and $g l m M$ virulence genes in the antrum and corpus mucosa was $33.8 \%$ and $22.1 \%$, respectively. Either of the genes was found in $58.8 \%$ of antrum and $57.3 \%$ of corpus mucosa. Presence of $c a q A$ and $g \operatorname{lm} M$ genes was in association with active and atrophic chronic gastritis. In conclusion, our study demonstrated that two thirds of morbidly obese patients undergoing bariatric surgery are infected with $H p$ and have a high prevalence of $c a g A$ and glmM virulence genes that points out the necessity for diagnostics and treatment of this infection before surgery.
\end{abstract}

Keywords: Helicobacter pylori; glmM gene; cagA gene; PCR; gastritis; obesity; virulence factors

\section{Introduction}

Helicobacter pylori $(\mathrm{Hp})$ is one of the most important human pathogens. $H p$ is a helix shaped, microaerophilic, Gram-negative bacteria. Some strains can form nonculturable coccoid form [1,2]. It colonizes and infects gastric epithelial cell surfaces and the overlying gastric mucin, which is a highly specialized niche [2]. According to the World Health Organization (WHO), more than $50 \%$ of the human population is infected [3], while over $80 \%$ of infected individuals are asymptomatic [4].

Previous studies suggest that $H p$ is genetically variable and certain genotypes may be detected only in certain populations [5,6]. Several virulence factors contribute to the inflammatory response towards $\mathrm{Hp}$ either by altering host signaling pathways important to maintaining tissue homeostasis in epithelia cells or by differentially stimulating innate immune cells [3,7]. Among the different genes involved in $\mathrm{Hp}$ pathogenicity, glmM (phosphoglucosamine mutase gene) and cag $\mathrm{A}$ (cytotoxin-associated gene $\mathrm{A}$ ) virulence genes have been demonstrated to be highly sensitive predictors of several clinical outcomes [2,3,8-10]. In particular, the glmM gene is highly conserved, has a high degree of sensitivity and specificity [11], while the caqA gene is one of the major virulence factors in $H p$ responsible for gastric pathology [12]. 
Prevalence of $H p$ infection varies around the world, and previous studies on obese patients have shown conflicting results: some studies have reported a higher prevalence [13-16], while others have shown a decreased prevalence when compared to the general population [17-19]. Hp infection is considered to be limiting access to bariatric surgery [15]. To date, there are no data about its prevalence in obese preoperative bariatric surgery patients in Estonia.

The aim of this study was to determine the prevalence of $H$. pylori and its virulence genes (cagA and $g l m M$ ) in the obese patients going into bariatric surgery. We also aimed to reveal the relationship between $\mathrm{Hp}$ and clinical data.

\section{Results}

\subsection{Clinical Indices and Endoscopic Findings}

The clinical indices of patients are presented in Table 1. The mean age of the patients was $45.3 \pm 9.6$ and the mean body mass index (BMI) was $44.7 \pm 4.8$. An increased white blood cell count (WBC) count was found in $22 \%$ of the subjects and raised C-reactive protein (hs-CRP) was found in $57 \%$ subjects. The level of fasting blood glucose was raised in $60 \%$ patients, while an increased low-density lipoprotein (LDL)-cholesterol level was found only in $1.5 \%$ of patients.

Table 1. Clinical data of study subjects (mean $\pm \mathrm{SD}$, range).

\begin{tabular}{cccc}
\hline \multicolumn{4}{c}{ Anthropometric Parameters } \\
\hline Parameter & Male $(\boldsymbol{n = 2 2 )}$ & Female $(\boldsymbol{n = 4 6 )}$ & Total $(\boldsymbol{n}=\mathbf{6 8})$ \\
\hline Age (years) & $45.6 \pm 10.1(29-65)$ & $45.2 \pm 9.5(19-61)$ & $45.3 \pm 9.6(19-65)$ \\
Height $(\mathrm{cm})$ & $180.6 \pm 8.2(160.0-198.0)$ & $165.4 \pm 6.3(150.0-180.0)$ & $170.4 \pm 10.0(150.0-198.0)$ \\
Weight $(\mathrm{kg})$ & $158.9 \pm 34.6(105.0-240.0)$ & $119.4 \pm 14.0(95.0-167.0)$ & $131.5 \pm 28.7(95.0-240.0)$ \\
BMI $\left(\mathrm{kg} / \mathrm{m}^{2}\right)$ & $44.8 \pm 5.2(37.0-53.0)$ & $44.6 \pm 4.6(35.0-53.0)$ & $44.7 \pm 4.8(35.0-53.0)$ \\
\hline \multicolumn{4}{c}{ Blood Parameters } \\
\hline Blood Parameter & Reference Range & Mean \pm SD (Range) \\
\hline WBC $\left(\times 10^{9} / \mathrm{L}\right)$ & $3.5-8.8$ & $7.8 \pm 2.7(3.5-17.0)$ \\
hs-CRP $(\mathrm{mg} / \mathrm{L})$ & $<5$ & $10.3 \pm 11.1(1.0-62.0)$ \\
\hline Hgb $(\mathrm{g} / \mathrm{L}) \quad$ male & $135-160$ & $130.7 \pm 14.1(121.0-182.0)$ \\
female & $120-140$ & $6.5 \pm 2.2(4.3-14.4)$ \\
Glycose $(\mathrm{mmol} / \mathrm{L})$ & $3.0-5.6$ & $5.0 \pm 1.1(2.9-7.8)$ \\
LDolesterol $(\mathrm{mmol} / \mathrm{L})$ & $3.9-7.8$ & $3.2 \pm 1.1(1.1-6.2)$ \\
\hline
\end{tabular}

Legend: BMI-body mass index; WBC-white blood cell count; Hgb-hemoglobin; hs-CRP-C-reactive protein; LDL-low-density lipoprotein.

An endoscopic examination was performed for the esophagus and stomach, followed by a histological analysis of the biopsy samples (Table 2). The most prevalent pathology in the antrum mucosa was chronic active gastritis in $27.8 \%$ of all cases, while in the corpus mucosa the most common diagnosis was superficial chronic gastritis in $38.3 \%$ patients. In total (antrum and/or corpus mucosa), the most prevalent diagnoses were superficial chronic gastritis and active chronic gastritis in $42.7 \%$ and $32.2 \%$ of patients, respectively. No detectable histopathological changes in the stomach were found only in three patients $(4.4 \%)$. 
Table 2. Endoscopic findings in patients with obesity (number and \%).

\begin{tabular}{cccccc}
\hline Endoscopic Findings & $\begin{array}{c}\text { Antrum } \\
\text { Mucosa Only }\end{array}$ & $\begin{array}{c}\text { Corpus } \\
\text { Mucosa Only }\end{array}$ & $\begin{array}{c}\text { Both Antrum } \\
\text { and Corpus }\end{array}$ & $\begin{array}{c}\text { Antrum and/or } \\
\text { Corpus Mucosa }\end{array}$ \\
\hline active & $13(19.0)$ & $3(4.4)$ & $6(8.8)$ & $22(32.2)$ \\
atrophic & $12(17.7)$ & $3(4.4)$ & $2(2.9)$ & $17(25.0)$ \\
Chronic & active and atrophic & $9(13.2)$ & $2(2.9)$ & $2(2.9)$ & $13(19.0)$ \\
gastritis & active and atrophic; with metaplasia & $3(4.4)$ & $0(0)$ & $0(0)$ & $3(4.4)$ \\
& atrophic; with metaplasia & $2(2.9)$ & $2(2.9)$ & $0(0)$ & $4(5.8)$ \\
& type unspecified & $9(13.2)$ & $4(5.9)$ & $2(2.9)$ & $15(22)$ \\
& type unspecified; with metaplasia & $0(0)$ & $1(1.5)$ & $0(0)$ & $1(1.5)$ \\
& superficial & $3(4.4)$ & $25(36.8)$ & $1(1.5)$ & $29(42.7)$ \\
& superficial; with metaplasia & $1(1.5)$ & $0(0)$ & $0(0)$ & $1(1.5)$ \\
\hline
\end{tabular}

\subsection{Prevalence of cagA and glmM Genes According to PCR Analysis}

The amplification of $\operatorname{cag} A$ and $g l m M$ genes of $H p$ was done for all stomach biopsies (Table 3). The prevalence of $\operatorname{cag} A$ and $g \operatorname{lm} M$ genes in the antrum mucosa were $45.6 \%$ and $47.0 \%$, while in the corpus mucosa it was $41.2 \%$ and $38.3 \%$, respectively. The coincidence of both cagA and glmM virulence genes in the antrum and corpus mucosa was $33.8 \%$ and $22.1 \%$, respectively. In total, either of the genes was found in $58.8 \%$ and $57.3 \%$ of the antrum and corpus mucosa, respectively (Table 3 ).

Table 3. Prevalence of virulence genes and H. pylori infection according to PCR and histological analysis in obese patients (number and \%).

\begin{tabular}{ccc}
\hline Biopsy Sample & Method of Analysis/Gene & Positive \\
\hline \multirow{4}{*}{ Antrum } & Histological analysis & $39(57.3)$ \\
& Only $\operatorname{cag} A$ & $8(11.8)$ \\
& Only $g l m M$ & $9(13.2)$ \\
& Both $\operatorname{cag} A$ and $g l m M$ & $23(33.8)$ \\
cagA and/or $g l m M$ & $40(58.8)$ \\
\hline \multirow{2}{*}{ Corpus } & Histological analysis & $38(55.9)$ \\
& Only cagA & $13(19.1)$ \\
& Only $g l m M$ & $11(16.2)$ \\
& Both cagA and $g l m M$ & $15(22.1)$ \\
Total & cagA and/or $g l m M$ & $39(57.3)$ \\
\hline \multirow{2}{*}{ Histological analysis } & $38(55.9)$ \\
& PCR analysis & $44(64.7)$ \\
\hline
\end{tabular}

The PCR method revealed a $H p$ infection quite similar to the histological method: $58.8 \%$ and $57.3 \%$ for the antrum and $57.3 \%$ and $55.9 \%$ for the corpus mucosa, respectively. In total, the PCR method revealed a $H p$ infection in $64.7 \%$ of obese patients that is slightly higher in comparison with histological analysis (55.9\%).

\subsection{Associations between Virulence Genes, Clinical Parameters and Histopathological Findings of Gastric Mucosa}

Statistically significant correlations between the histopathological findings for the gastric mucosa and the presence of virulence genes are presented in Table 4 . The presence of precancerous conditions (atrophic gastritis and/or metaplasia) in the antrum mucosa was associated with the presence of cag $\mathrm{A}$ and $g \operatorname{lm} M$ genes in $50.0 \%$ for both genes of all cases, while for the corpus mucosa this was $50.0 \%$ and $29.4 \%$, respectively (Table 5). The prevalence of the cagA gene was lower in patients without atrophic gastritis and metaplasia, however, this difference was not statistically significant. 
Table 4. Correlations between histological findings and present virulence genes.

\begin{tabular}{cccc}
\hline Histological Findings & Virulence Genes & Correlation Coefficient (r) & $p$-Value \\
\hline $\begin{array}{c}\text { Chronic active gastritis } \\
\text { (antrum mucosa) }\end{array}$ & $g \operatorname{lm} M$ (antrum mucosa) & 0.27 & 0.028 \\
\hline $\operatorname{glm} M$ (corpus mucosa) & 0.32 & 0.008 \\
\hline Chronic active gastritis & $g \operatorname{lm} M$ (antrum mucosa) & 0.33 & 0.007 \\
(corpus mucosa) & $\operatorname{cag} A$ (antrum mucosa) & 0.25 & 0.038 \\
\hline Chrnoic active and atrophic & $\operatorname{cag} A$ (antrum mucosa) & 0.27 & 0.024 \\
gastritis (corpus mucosa) & cagA (corpus mucosa) & 0.30 & 0.014 \\
\hline
\end{tabular}

Table 5. Association between patients with atrophic gastritis and/or metaplasia and H. pylori (number and \%).

\begin{tabular}{ccccc}
\hline \multirow{2}{*}{ Diagnosis } & \multicolumn{2}{c}{ Antrum } & \multicolumn{2}{c}{ Corpus } \\
\cline { 2 - 5 } & CagA Gene & GlmM Gene & CagA Gene & GlmM Gene \\
\hline Patients with atrophic gastritis and/or metaplasia $(n=34)$ & $17(50.0)$ & $17(50.0)$ & $17(50.0)$ & $10(29.4)$ \\
\hline Patients without atrophic gastritis and/or metaplasia $(n=34)$ & $14(41.2)$ & $15(44.1)$ & $11(32.4)$ & $16(47.1)$ \\
\hline
\end{tabular}

There were no correlations between patients' gender, age, BMI and the presence of $H p$ in the antral and corpuscular gastric mucosa. No statistical differences in blood parameters were found between $\mathrm{Hp}$ positive and negative patients, though, hs-CRP was increased in $63.6 \%(28 / 44)$ of $H p$ positive obese patients (Table 6).

Table 6. Blood parameters of patients with and without H. pylori infection (mean \pm SD, range).

\begin{tabular}{|c|c|c|c|}
\hline \multirow{2}{*}{ Blood Parameter } & \multicolumn{2}{|c|}{ Both Antrum and Corpus } & \multirow{2}{*}{$p$-Value * } \\
\hline & H. pylori Positive & H. pylori Negative & \\
\hline \multirow{2}{*}{$\begin{array}{l}\mathrm{WBC}\left(\times 10^{9} / \mathrm{L}\right) \\
\mathrm{hs}-\mathrm{CRP}(\mathrm{mg} / \mathrm{L})\end{array}$} & $7.4 \pm 2.1$ & $7.9 \pm 3.2$ & 0.842 \\
\hline & $10.2 \pm 10.9$ & $7.3 \pm 7.2$ & 0.205 \\
\hline \multirow{3}{*}{$\operatorname{Hgb}(\mathrm{g} / \mathrm{L}) \quad \begin{array}{c}\text { male } \\
\text { female }\end{array}$} & $150.0 \pm 14.6$ & $152.4 \pm 12.1$ & 0.669 \\
\hline & $135.6 \pm 11.5$ & $134.7 \pm 18.1$ & 0.973 \\
\hline & $6.7 \pm 2.0$ & $6.0 \pm 1.8$ & 0.154 \\
\hline Cholesterol (mmol/L) & $5.3 \pm 1.1$ & $5.0 \pm 0.9$ & 0.238 \\
\hline LDL-cholesterol (mmol/L) & $3.4 \pm 1.2$ & $3.1 \pm 0.9$ & 0.369 \\
\hline
\end{tabular}

* Mann-Whitney rank sum test was used for comparison of the groups, except for the male hemoglobin (Hgb) where $t$-test was used due to parametric distribution of data.

\section{Discussion}

The present study revealed a remarkably high prevalence of both gastritis $(96 \%)$ and $\mathrm{Hp}$ infection $(65 \%)$ among preoperative bariatric surgery patients, the latter being confirmed by two methods, PCR and histological analysis. $H p$ virulence genes, caqA and $g l m M$ were associated with different forms of chronic gastritis both in the antrum and corpus. $\mathrm{Hp}$ was not associated with the demographic data and blood parameters of obese patients.

According to the literature, mostly serology, stool antigen assays and urea breath tests have been used for the detection of $H p$ infection in obese patients [15]. Histological investigation also has excellent sensitivity and specificity, especially when specific immunostaining is used $[15,20]$. Vanek et al. have compared serology and histology and found good accordance between the two methods [21]. In our study, we also combined two approaches: histology and the detection of $H$. pylori virulence genes such as $\operatorname{glm} M$ and $\operatorname{cag} A$ by the polymerase chain reaction (PCR) method.

Among the different genes involved in the pathogenicity of $H p$, the $g \operatorname{lm} M$ (phosphoglucosamine mutase gene) and cagA (cytotoxin-associated gene A) virulence genes have been demonstrated to be highly sensitive predictors of severe clinical outcomes [2,3,9]. CagA is the most-studied virulence factor 
of $H p$, which is a 120-145 kDa protein encoded on the cag pathogenicity island (PAI) [22]. It contains 31 potential coding regions which encodes a type IV secretion system (T4SS) through which cagA is delivered into host cells [23-25]. Phosphorylated or nonphosphorylated cagA can interact with host proteins that regulate cell growth, cell motility and cell polarity altering host cell signaling. Thus, cag $A$ can promote cells to accumulate multiple genetic and epigenetic changes involved in gastric carcinogenesis and gastric adenocarcinoma development [26]. Also, it is highly antigenic, inducing interleukin-8 (IL-8) secretion by gastric epithelial cells [27]. It is one of the mechanisms involved in forming the neutrophilic infiltration of epithelium and mucous. Such pathological processes can lead to the formation of lymphoid follicles and epithelial damage of varying severity $[8,28]$.

The housekeeping glmM gene encodes a phosphoglucosamine mutase, an enzyme catalyzing the interconversion of glucosamine-6-phosphate into glucosamine-1-phosphate, which is subsequently transformed into $\mathrm{N}$-acetylglucosamine. This monosaccharide is one of the main cytoplasmic precursors of bacterial cell wall murein and outer membrane lipopolysaccharides. Consequently, the glmM gene is essential for bacterial cell growth and assists directly with cell wall synthesis. The glmM gene is highly conserved between strains [29,30]. The presence of the glmM gene in Hp-positive obese persons has not been described before. One of the advantages of using this gene to identify $H p$ is its high sensitivity and specificity, since it has the detection rate of 10 to $100 \mathrm{H}$. pylori cells, which is significantly better than histology [31].

Previous studies have shown that the $H p$-containing cagA gene is associated with the development of chronic active gastritis (AG) [32], peptic ulceration [8,10,33] and athrophic gastritis with an increased risk of gastric cancer $[34,35]$ while the glmM gene is associated with the development of chronic superficial gastritis as well as intestinal metaplasia (IM), gastric ulcers and gastric dysplasia, and it was less expressed in chronic gastric ulcers and atrophic gastritis [36,37]. Our study revealed that both genes were associated with chronic active and atrophic gastritis in the antrum and corpus, while the presence of the $g l m M$ gene was associated with chronic active gastritis in the antrum, which is different from the data of Helaly et al. [36]. Also, a half of the morbidly obese patients suffered from atrophic gastritis and/or metaplasia in our study, which are the main precursors of gastric cancer. According to Correa's theory, the formation of gastric cancer is a multistep and multifactorial process where the presence of $H p$ infection is one of the main factors. Gastritis begins from superficial gastritis and may progress into atrophic gastritis, metaplasia, dysplasia and gastric cancer [36]. The majority of studies determining the prevalence of AG and IM around the world touch on the general population, but not morbidly obese patients. The prevalence of AG and IM in Estonian obese patients is quite similar to the data of Korean, Chinese and Japanese rural populations $(42.7 \%, 63.8 \%$ and $55.5 \%$ for AG, respectively) [37-39] while it differs from studies of German (6.0\% for AG), Swedish ( $0.6 \%$ for AG) and US rural populations (15.0\% for IM) [40-42].

Using a combination of two tests, our study determined the prevalence of $\mathrm{Hp}$ in preoperative bariatric patients in Estonia to be $64.7 \%$. To our knowledge, this report is the first to reveal the virulence factors of $\mathrm{Hp}$ among preoperative bariatric patients in Estonia, although $\mathrm{Hp}$ in Estonian obese patients has been detected earlier using the serological method, with a prevalence of 51.7\% [38]. Our study did not include a non-obese control group, but previous studies have revealed the $\mathrm{Hp}$ prevalence in the adult Estonian population to be $69 \%$ [43], which is nearly similar to the present study. Hp infection has large disparity between developed and developing countries [39]. Although Estonia belongs to the European countries, the prevalence of $H p$ infection is still quite high in comparison to other countries.

According to the previous data, the prevalence of $\mathrm{Hp}$ infection in morbidly obese patients is still controversial. It has been shown to vary from $2.2 \%$ in Australia [42] and $8.7 \%$ in Germany [40] to $85.5 \%$ in a Saudi cohort [41]. The increased prevalence (40.93\%) of $\mathrm{Hp}$ infection was found in Chinese patients with higher BMI levels in comparison with lower ones [44]. At the same time, some studies have shown no correlation [45,46] or a negative correlation [42] between obesity and the prevalence of $H p$ infection. A study of the Japanese population has shown lower BMIs in patients with gastritis than in patients without gastritis [47]. In our study we did not find an association between $\mathrm{Hp}$ and BMI. 
The question why infected and not infected morbidly obese patients may have similar BMIs, remains to be answered. The knowledge of the pathophysiology between $\mathrm{Hp}$ and obesity is limited due to the complex nature of the organism [46]. It is possible that many factors such as geographical region and social status can play a role in the pathogenesis of $H p$ infection in certain obese patients. A study by Fontana et al. [48] demonstrated that agonist-stimulated production of interferon- $\gamma$ (IFN-gamma) and macrophage chemoattractant protein-1 (MCP-1) are significantly suppressed in subjects with obesity. Weight loss completely normalizes the ability of stimulated peripheral blood mononuclear cells (PBMCs) to produce MCP-1 and IFN-gamma. Thus, obese patients have an increased risk of bacterial and viral infections [48].

Our study did not reveal an association between $\mathrm{Hp}$ and age that is in accordance with that of Helaly et al. [34]. However, contrary data have been shown by some other studies $[45,46]$ where obese patients with $\mathrm{Hp}$ infection were significantly older compared to those without infection. This tendency can be related to alterations in immune system functions during human organism ageing as well as lower hygiene levels during the youth of elderly people.

We found that more than half of Hp positive obese patients had increased hs-CRP levels in serum, which is in accordance with other data [49]. In a study of Turkish patients it was demonstrated that serum levels of hs-CRP were significantly reduced in most $H p$ positive patients after antibiotic eradication therapy [50].

A previous animal study has demonstrated that $\mathrm{Hp}$ colonization may decrease fasting blood glucose levels and improve glucose tolerance [51]. In our study, mean glucose levels tended to be higher in $H p$ positive patients, but due to the small sample size this tendency was not statistically significant.

There were a few limitations in our study. Firstly, we did not have a control group for comparison of the prevalence of $\mathrm{Hp}$ among the healthy population that may have considerably changed in recent years. Secondly, the current study was limited because of the small sample size $(n=68)$.

\section{Materials and Methods}

\subsection{Patients}

The study was carried out at Department of Microbiology, Institute of Biomedicine and Translational Medicine, University of Tartu in collaboration with Tartu University Hospital. The study group was formed of 68 patients (46 females, 22 males; age range: 19-65 years, mean age $45.3 \pm 9.6$ years; mean body mass index (BMI) $44.7 \pm 4.8$ ) attending the Surgery Clinic of Tartu University Hospital between March 2015 and December 2016. BMI was calculated as described [52]. Blood samples were obtained after $8 \mathrm{~h}$ of fasting and stored immediately at $4{ }^{\circ} \mathrm{C}$. Laboratory analyses were performed with standard methods using certified assays in the United Laboratory of Tartu University Hospital. Intervals for routine laboratory tests proposed by the Nordic Reference Interval Project (NORIP, available online: http:/ / www.furst.no/norip/) were used as references.

\subsection{Ethics Statement}

The present study was conducted according to the guidelines laid down in the Declaration of Helsinki. The study was approved by the Ethics Review Committee on Human Research of Tartu University, Estonia (protocol No. 244/T-15, 17 February 2015 of approval). Participation in the study was voluntary. Written informed consent was obtained from all study subjects.

\subsection{Endoscopic Examination of the Esophagus, Stomach and Duodenum}

Gastrointestinal endoscopy was performed by an experienced endoscopist on an empty stomach (no taking food at least four hours before procedure). In every patient, two biopsies from the gastric antrum ( $2 \mathrm{~cm}$ from the pyloric ring) and two biopsies from the corpus were collected for histological evaluation; the same package of biopsies was collected for molecular studies. The stomach and esophagus were examined; and all the endoscopic findings were registered. 


\subsection{Gastric Biopsies Processing}

Formalin-fixed, paraffin-embedded gastric biopsy specimens from the antrum and corpus mucosa were stained with hematoxylin and eosin, and with a modified Giemsa stain. The state of the gastric mucosa and the presence of $H p$ in histological sections were assessed to grade the severity of gastritis, intestinal metaplasia and presence of $H p$ infection. The remaining biopsies used for molecular applications were stored frozen at $-80^{\circ} \mathrm{C}$ until processed.

\subsection{Molecular Analysis}

The frozen biopsy specimens were suspended in $500 \mu \mathrm{L}$ of lysis buffer $(200 \mathrm{mM}$ Tris- $\mathrm{HCl}$ (pH 8.0), $25 \mathrm{mM}$ ethylenediaminetetraacetic acid (EDTA), $300 \mathrm{mM} \mathrm{NaCl}, 1.2 \%$ sodium dodecyl sulfate) and $20 \mu \mathrm{L}$ of proteinase $\mathrm{K}(400 \mu \mathrm{g} / \mathrm{mL})$ for DNA extraction. The mixture was incubated at $37^{\circ} \mathrm{C}$ for $24 \mathrm{~h}$. The procedure of DNA extraction was continued according to the tissue protocol of QIAamp DNA Blood Mini Kit (Qiagen, Hilden, Germany). Extracted DNA was used for subsequent PCR experiments. The DNA amplification was performed in reaction volume of $50 \mu \mathrm{L}$ containing $25 \mu \mathrm{L}$ of Hot Start Buffer (Fermentas, Vilnius, Lithuania); $1 \mu \mathrm{M}$ of each primer, (5'-ATA ATG CTA AAT TAG-3 and $5^{\prime}$-TTA GAA TAA TCA AGA- $3^{\prime}$ for amplification the cag $A$ gene; $5^{\prime}$-AAG CTT TTA GGG GTG- $3^{\prime}$ and $5^{\prime}$-AAG CTT ACT TTC TAA- $3^{\prime}$ for amplification glmM gene and $5 \mu \mathrm{L}$ of extracted DNA $[9,53,54]$. The mixtures were placed into a PCR thermocycler (Mastercycler gradient, Eppendorf, Hamburg, Germany). PCR conditions were as follows: an initial denaturation $\left(94{ }^{\circ} \mathrm{C}, 2 \mathrm{~min}\right), 35$ cycles of denaturation $\left(94^{\circ} \mathrm{C}, 2 \mathrm{~min}\right)$, annealing $\left(55^{\circ} \mathrm{C}, 2 \mathrm{~min}\right)$, and extension $\left(72{ }^{\circ} \mathrm{C}, 2 \mathrm{~min}\right)$, with a final extension $\left(72{ }^{\circ} \mathrm{C}, 10 \mathrm{~min}\right)$. PCR products were identified using agarose gel electrophoresis on $2 \%$ agarose gel, ethidium bromide staining, and UV transillumination.

\subsection{Statistical Analysis}

For statistical analysis, SigmaPlot 12.0 (Systat Software Inc., San Jose, CA, USA) software was used. The differences between the groups were analyzed using the Mann-Whitney rank sum test and $t$-test. Spearman rank order correlation analysis was used to find associations between the markers. Statistical significance was assumed at $p<0.05$ for all parameters.

\section{Conclusions}

In conclusion, our study demonstrated that two thirds of morbidly obese patients undergoing bariatric surgery in Estonia are infected with $\mathrm{Hp}$, while the prevalence of the virulence genes cag $\mathrm{A}$ and/or $g \operatorname{lm} M$ accounted for nearly $60 \%$ of cases. The presence of these genes is associated with a high prevalence of active and atrophic chronic gastritis that in turn bears higher risks of serious consequences for the patients. The pathological changes and processes induced by $H p$ in the gastric mucosa may interfere with the welfare and health of operated subjects in long run, which points out the necessity for the diagnosis and treatment of this infection before surgery.

Acknowledgments: This study was supported by Estonian Research Council (grant No. IUT34-19), Estonian Ministry of Education and Research (grant No. KOGU-HUMB) and Enterprise Estonia (grant No. EU48695). We thank Made Aljas and Irja Roots for technical assistance.

Author Contributions: Reet Mändar and Toomas Sillakivi conceived and designed the experiment; Toomas Sillakivi and Natalja Šebunova conducted the study and collected the samples; Natalja Šebunova and Jelena Štšepetova performed the experiments and analyzed the data. All authors contributed to paper writing. All authors have read and approved the final manuscript.

Conflicts of Interest: We declare that we have no conflicts of interest relevant to this study. 


\section{References}

1. Hegarty, J.P.; Dowd, M.T.; Baker, K.H. Occurrence of Helicobacter pylori in surface water in the United States. J. Appl. Microbiol. 1999, 87, 697-701. [CrossRef] [PubMed]

2. Shahamat, M.; Alavi, M.; Watts, J.E.; Gonzalez, J.M.; Sowers, K.R.; Maeder, D.W.; Robb, F.T. Development of two PCR-based techniques for detecting helical and coccoid forms of Helicobacter pylori. J. Clin. Microbiol. 2004, 42, 3613-3619. [CrossRef] [PubMed]

3. Kalali, B.; Mejias-Luque, R.; Javaheri, A.; Gerhard, M. H. pylori virulence factors: Influence on immune system and pathology. Mediat. Inflamm. 2014, 2014, 426309. [CrossRef] [PubMed]

4. Palli, D.; Masala, G.; Del Giudice, G.; Plebani, M.; Basso, D.; Berti, D.; Numans, M.E.; Ceroti, M.; Peeters, P.H.; Bueno de Mesquita, H.B.; et al. CagA+Helicobacter pylori infection and gastric cancer risk in the EPIC-EURGAST study. Int. J. Cancer 2007, 120, 859-867. [CrossRef] [PubMed]

5. Bibi, F.; Alvi, S.A.; Sawan, S.A.; Yasir, M.; Sawan, A.; Jiman-Fatani, A.A.; Azhar, E.I. Detection and genotyping of Helicobacter pylori among gastric ulcer and cancer patients from Saudi Arabia. Pak. J. Med. Sci. 2017, 33, 320-324. [CrossRef] [PubMed]

6. Sicinschi, L.A.; Correa, P.; Peek, R.M., Jr.; Camargo, M.C.; Delgado, A.; Piazuelo, M.B.; Romero-Gallo, J.; Bravo, L.E.; Schneider, B.G. Helicobacter pylori genotyping and sequencing using paraffin-embedded biopsies from residents of colombian areas with contrasting gastric cancer risks. Helicobacter 2008, 13, $135-145$. [CrossRef] [PubMed]

7. Cellini, L.; Donelli, G. Virulence factors of Helicobacter pylori. Microb. Ecol. Health Dis. 2000, 12, $259-262$.

8. Andreson, H.; Loivukene, K.; Sillakivi, T.; Maaroos, H.I.; Ustav, M.; Peetsalu, A.; Mikelsaar, M. Association of cagA and vacA genotypes of Helicobacter pylori with gastric diseases in Estonia. J. Clin. Microbiol. 2002, 40, 298-300. [CrossRef] [PubMed]

9. Lu, J.J.; Perng, C.L.; Shyu, R.Y.; Chen, C.H.; Lou, Q.; Chong, S.K.; Lee, C.H. Comparison of five PCR methods for detection of Helicobacter pylori DNA in gastric tissues. J. Clin. Microbiol. 1999, 37, 772-774. [PubMed]

10. Sillakivi, T.; Aro, H.; Ustav, M.; Peetsalu, M.; Peetsalu, A.; Mikelsaar, M. Diversity of Helicobacter pylori genotypes among Estonian and Russian patients with perforated peptic ulcer, living in Southern Estonia. FEMS Microbiol. Lett. 2001, 195, 29-33. [CrossRef] [PubMed]

11. Ho, G.Y.; Windsor, H.M. Accurate diagnosis of Helicobacter pylori. Polymerase chain reaction tests. Gastroenterol. Clin. N. Am. 2000, 29, 903-915. [CrossRef]

12. Essawi, T.; Hammoudeh, W.; Sabri, I.; Sweidan, W.; Farraj, M.A. Determination of Helicobacter pylori virulence genes in gastric biopsies by PCR. ISRN Gastroenterol. 2013, 2013, 606258. [CrossRef] [PubMed]

13. Erim, T.; Cruz-Correa, M.R.; Szomstein, S.; Velis, E.; Rosenthal, R. Prevalence of Helicobacter pylori seropositivity among patients undergoing bariatric surgery: A preliminary study. World J. Surg. 2008, 32, 2021-2025. [CrossRef] [PubMed]

14. Nassir, R.; Qi, L.; Kosoy, R.; Garcia, L.; Allison, M.; Ochs-Balcom, H.M.; Tylavsky, F.; Manson, J.E.; Shigeta, R.; Robbins, J.; et al. Relationship between adiposity and admixture in African-American and Hispanic-American women. Int. J. Obes. (Lond.) 2012, 36, 304-313. [CrossRef] [PubMed]

15. Carabotti, M.; D’Ercole, C.; Iossa, A.; Corazziari, E.; Silecchia, G.; Severi, C. Helicobacter pylori infection in obesity and its clinical outcome after bariatric surgery. World J. Gastroenterol. 2014, 20, 647-653. [CrossRef] [PubMed]

16. Mocanu, V.; Dang, J.T.; Switzer, N.; Skubleny, D.; Shi, X.; de Gara, C.; Birch, D.W.; Karmali, S. The effect of Helicobacter pylori on postoperative outcomes in patients undergoing bariatric surgery: A systematic review and meta-analysis. Obes. Surg. 2017. [CrossRef] [PubMed]

17. Kyriazanos, I.D.; Sfiniadakis, I.; Gizaris, V.; Hountis, P.; Hatziveis, K.; Dafnopoulou, A.; Datsakis, K. The incidence of Helicobacter pylori infection is not increased among obese young individuals in Greece. J. Clin. Gastroenterol. 2002, 34, 541-546. [CrossRef] [PubMed]

18. Maksud, F.A.; Alves, J.S.; Diniz, M.T.; Barbosa, A.J. Density of ghrelin-producing cells is higher in the gastric mucosa of morbidly obese patients. Eur. J. Endocrinol. 2011, 165, 57-62. [CrossRef] [PubMed]

19. Wu, M.S.; Lee, W.J.; Wang, H.H.; Huang, S.P.; Lin, J.T. A case-control study of association of Helicobacter pylori infection with morbid obesity in Taiwan. Arch. Intern. Med. 2005, 165, 1552-1555. [CrossRef] [PubMed] 
20. Malfertheiner, P.; Megraud, F.; O’Morain, C.A.; Atherton, J.; Axon, A.T.; Bazzoli, F.; Gensini, G.F.; Gisbert, J.P.; Graham, D.Y.; Rokkas, T.; et al. Management of Helicobacter pylori infection-The Maastricht IV/Florence consensus report. Gut 2012, 61, 646-664. [CrossRef] [PubMed]

21. Vanek, V.W.; Catania, M.; Triveri, K.; Woodruff, R.W., Jr. Retrospective review of the preoperative biliary and gastrointestinal evaluation for gastric bypass surgery. Surg. Obes. Relat. Dis. 2006, 2, 17-22, discussioon 22-23. [CrossRef] [PubMed]

22. Shiota, S.; Suzuki, R.; Yamaoka, Y. The significance of virulence factors in Helicobacter pylori. J. Dig. Dis. 2013, 14, 341-349. [CrossRef] [PubMed]

23. Asahi, M.; Azuma, T.; Ito, S.; Ito, Y.; Suto, H.; Nagai, Y.; Tsubokawa, M.; Tohyama, Y.; Maeda, S.; Omata, M.; et al. Helicobacter pylori CagA protein can be tyrosine phosphorylated in gastric epithelial cells. J. Exp. Med. 2000, 191, 593-602. [CrossRef] [PubMed]

24. Backert, S.; Selbach, M. Role of type IV secretion in Helicobacter pylori pathogenesis. Cell. Microbiol. 2008, 10, 1573-1581. [CrossRef] [PubMed]

25. Censini, S.; Lange, C.; Xiang, Z.; Crabtree, J.E.; Ghiara, P.; Borodovsky, M.; Rappuoli, R.; Covacci, A. cag, a pathogenicity island of Helicobacter pylori, encodes type I-specific and disease-associated virulence factors. Proc. Natl. Acad. Sci. USA 1996, 93, 14648-14653. [CrossRef] [PubMed]

26. Hatakeyama, M.; Higashi, H. Helicobacter pylori CagA: A new paradigm for bacterial carcinogenesis. Cancer Sci. 2005, 96, 835-843. [CrossRef] [PubMed]

27. Makarenko, V.P.; Voropajeva, A.V. Genes cagA, vacAm1, vacAm2, vacAs1, vacAs2 and babA of H. pylori in patients with duodenal ulcer and chronic gastritis. Vestn. Vitebsk State Med. Univ. 2004, 3, 74-77.

28. Mayev, V.; Govorun, V.M.; Kucheryavy, Y.A.; Generozov, E.V.; Lisitsina, I.A.; Budanova, Y.A. Interleukin-8 genetic polymorphism at chronic gastritis and peptic ulcer of duodenum associated to Helicobacter pylori. Genet. Perspect. Gastroenterol. Hepatol. 2008, 6, 1-9.

29. De Reuse, H.; Labigne, A.; Mengin-Lecreulx, D. The Helicobacter pylori ureC gene codes for a phosphoglucosamine mutase. J. Bacteriol. 1997, 179, 3488-3493. [CrossRef] [PubMed]

30. Kansau, I.; Raymond, J.; Bingen, E.; Courcoux, P.; Kalach, N.; Bergeret, M.; Braimi, N.; Dupont, C.; Labigne, A. Genotyping of Helicobacter pylori isolates by sequencing of PCR products and comparison with the RAPD technique. Res. Microbiol. 1996, 147, 661-669. [CrossRef]

31. Ho, B.; Marshall, B.J. Accurate diagnosis of Helicobacter pylori. Serologic testing. Gastroenterol. Clin. N. Am. 2000, 29, 853-862. [CrossRef]

32. Peek, R.M., Jr.; Miller, G.G.; Tham, K.T.; Perez-Perez, G.I.; Cover, T.L.; Atherton, J.C.; Dunn, G.D.; Blaser, M.J. Detection of Helicobacter pylori gene expression in human gastric mucosa. J. Clin. Microbiol. 1995, 33, $28-32$. [PubMed]

33. Walker, M.M.; Crabtree, J.E. Helicobacter pylori infection and the pathogenesis of duodenal ulceration. Ann. N. Y. Acad. Sci. 1998, 859, 96-111. [CrossRef] [PubMed]

34. Covacci, A.; Censini, S.; Bugnoli, M.; Petracca, R.; Burroni, D.; Macchia, G.; Massone, A.; Papini, E.; Xiang, Z.; Figura, N.; et al. Molecular characterization of the 128-kDa immunodominant antigen of Helicobacter pylori associated with cytotoxicity and duodenal ulcer. Proc. Natl. Acad. Sci. USA 1993, 90, 5791-5795. [CrossRef] [PubMed]

35. Webb, P.M.; Crabtree, J.E.; Forman, D. Gastric cancer, cytotoxin-associated gene A-positive Helicobacter pylori, and serum pepsinogens: An international study. The Eurogst Study Group. Gastroenterology 1999, 116, 269-276. [CrossRef]

36. Helaly, G.H.; El-Afandy, N.M.; Hassan, A.A.; Dowidar, N.L.; Sharaf, S.M. Diagnostic Value of Housekeeping [glmM] Gene Expression in Antral Biopsies in Comparison to Rapid Urease Test and Histological Detection of Helicobacter pylori Infection. Egypt. J. Med. Microbiol. 2009, 18, 119-130.

37. Salehi, Z.; Abadi, A.S.; Ismail, P.B.; Kqueen, C.Y.; Jelodar, M.H.; Kamalidehghan, B. Evaluation of Helicobacter pylori vacA genotypes in Iranian patients with peptic ulcer disease. Dig. Dis. Sci. 2009, 54, 2399-2403. [CrossRef] [PubMed]

38. Thjodleifsson, B.; Olaffson, L.; Gislason, D.; Gislason, T.; Jõgi, R.; Janson, C. Infections and obesity: A multinational epidemiological study. Scand. J. Infect. Dis. 2008, 40, 381-386. [CrossRef] [PubMed]

39. Mascie-Taylor, C.G.; Karim, E. The burden of chronic disease. Science 2003, 302, 1921-1922. [CrossRef] [PubMed] 
40. Kuper, M.A.; Kratt, T.; Kramer, K.M.; Zdichavsky, M.; Schneider, J.H.; Glatzle, J.; Stuker, D.; Konigsrainer, A.; Brucher, B.L. Effort, safety, and findings of routine preoperative endoscopic evaluation of morbidly obese patients undergoing bariatric surgery. Surg. Endosc. 2010, 24, 1996-2001. [CrossRef] [PubMed]

41. Al-Akwaa, A.M. Prevalence of Helicobacter pylori infection in a group of morbidly obese Saudi patients undergoing bariatric surgery: A preliminary report. Saudi J. Gastroenterol. 2010, 16, 264-267. [CrossRef] [PubMed]

42. Lender, N.; Talley, N.J.; Enck, P.; Haag, S.; Zipfel, S.; Morrison, M.; Holtmann, G.J. Review Article: Associations Between Helicobacter pylori and Obesity-An Ecological Study. Aliment. Pharmacol. Ther. 2014, 40, 24-31. [CrossRef] [PubMed]

43. Thjodleifsson, B.; Asbjörnsdottir, H.; Sigurjonsdottir, R.B.; Gíslason, D.; Olafsson, I.; Cook, E.; Gíslason, T.; Jogi, R.; Janson, C. Seroprevalence of Helicobacter pylori and cagA antibodies in Iceland, Estonia and Sweden. Scand. J. Infect. Dis. 2007, 39, 683-689. [CrossRef] [PubMed]

44. Zhang, Y.; Du, T.; Chen, X.; Yu, X.; Tu, L.; Zhang, C. Association between Helicobacter pylori infection and overweight or obesity in a Chinese population. J. Infect. Dev. Ctries. 2015, 9, 945-953. [CrossRef] [PubMed]

45. Ioannou, G.N.; Weiss, N.S.; Kearney, D.J. Is Helicobacter pylori seropositivity related to body mass index in the United States? Aliment. Pharmacol. Ther. 2005, 21, 765-772. [CrossRef] [PubMed]

46. Verma, S.; Sharma, D.; Kanwar, P.; Sohn, W.; Mohanty, S.R.; Tortolani, A.J.; Gorecki, P. Prevalence of Helicobacter pylori infection in bariatric patients: A histologic assessment. Surg. Obes. Relat. Dis. 2013, 9, 679-685. [CrossRef] [PubMed]

47. Torisu, T.; Matsumoto, T.; Takata, Y.; Ansai, T.; Soh, I.; Awano, S.; Nakamichi, I.; Kagiyama, S.; Sonoki, K.; Yoshida, A.; et al. Atrophic gastritis, but not antibody to Helicobacter pylori, is associated with body mass index in a Japanese population. J. Gastroenterol. 2008, 43, 762-766. [CrossRef] [PubMed]

48. Fontana, L.; Eagon, J.C.; Colonna, M.; Klein, S. Impaired mononuclear cell immune function in extreme obesity is corrected by weight loss. Rejuv. Res. 2007, 10, 41-46. [CrossRef] [PubMed]

49. Jafarzadeh, A.; Hassanshahi, G.H.; Nemati, M. Serum levels of high-sensitivity C-reactive protein (hs-CRP)in Helicobacter pylori-infected peptic ulcer patients and its association with bacterial CagA virulence factor. Dig. Dis. Sci. 2009, 54, 2612-2616. [CrossRef] [PubMed]

50. Kanbay, M.; Gur, G.; Yucel, M.; Yilmaz, U.; Boyacioglu, S. Does eradication of Helicobacter pylori infection help normalize serum lipid and CRP levels? Dig. Dis. Sci. 2005, 50, 1228-1231. [CrossRef] [PubMed]

51. Bassaganya-Riera, J.; Dominguez-Bello, M.G.; Kronsteiner, B.; Carbo, A.; Lu, P.; Viladomiu, M.; Pedragosa, M.; Zhang, X.; Sobral, B.W.; Mane, S.P.; et al. Helicobacter pylori colonization ameliorates glucose homeostasis in mice through a PPAR gamma-dependent mechanism. PLoS ONE 2012, 7, e50069. [CrossRef] [PubMed]

52. World Health Organization. Physical Status: The Use and Interpretation of Anthropometry; WHO Technical Report Series; World Health Organization: Geneva, Switzerland, 1995; Volume 854, p. 9.

53. Bickley, J.; Owen, R.J.; Fraser, A.G.; Pounder, R.E. Evaluation of the polymerase chain reaction for detecting the urease $C$ gene of Helicobacter pylori in gastric biopsy samples and dental plaque. J. Med. Microbiol. 1993, 39, 338-344. [CrossRef] [PubMed]

54. Domingo, D.; Alarcon, T.; Prieto, N.; Sanchez, I.; Lopez-Brea, M. cagA and vacA status of Spanish Helicobacter pylori clinical isolates. J. Clin. Microbiol. 1999, 37, 2113-2114. [PubMed]

(C) 2018 by the authors. Licensee MDPI, Basel, Switzerland. This article is an open access article distributed under the terms and conditions of the Creative Commons Attribution (CC BY) license (http://creativecommons.org/licenses/by/4.0/). 